Industrial Health, 1976, 14, 87.

\title{
MANGANESE INDUCED MORPHOLOGICAL AND BIOCHEMICAL CHANGES IN THE BRAIN OF IRON DEFICIENT RATS*
}

\author{
Girja S. SHUKLA and Satya V. Chandra \\ Industrial Toxicology Research Centre, Lucknow, U. P., India
}

(Received March 8, 1976)

\begin{abstract}
Rats were rendered iron deficient by maintaining them on iron deficient diet. Manganese chloride $(15 \mathrm{mg} / \mathrm{kg}$ ) was administered intraperitoneally daily for 15 days to these rats. Morphological studies in the brain tissue showed neuronal degeneration scattered in the cerebral cortex. Manganese produced marked enzymic alterations in the brain of iron deficient rats as compared to similar treatment to rats fed on normal diet. Marked morphological and enzymic alterations in the brain of manganese treated iron deficient rats appear to be due to greater accumulation of the metal in brain tissue of these animals as compared to controls. It may, therefore, be suggested that workers in manganese industry should be checked frequently for iron deficiency as a prophylactic measure.
\end{abstract}

Various uses of manganese and its toxic effects on human system are well documented $^{1)}$. Large number of workers are exposed to the dust or fumes of manganese during industrial application of this metal but only a certain percentage among them develop chronic manganese encephalopathy. This indicates that the victims of manganese poisoning are being selected among exposed workers by some factors which may predispose unusual flooding of the brain with this metal. Evidence of increased manganese absorption in the presence of iron deficiency in individuals led Mena et al. ${ }^{2}$ ) to suspect this metabolic factor being responsible to render an individual more susceptibe for manganese poisoning among exposed workers.

Previous reports from this laboratory have shown that manganese produces enhanced toxic effects on liver and kindneys of the iron deficient rats ${ }^{3,4)}$. Since the most deliterious effects of manganese are produced in the nervous system of experimental animals and in the humans exposed to this metal ${ }^{5-7}$, it was considered worthwhile to investigate the effects of this metal on the brain tissue of iron deficient rats. Morphological and biochemical changes have been correlated with the amount of manganese present in this organ.

* Part of this work has been presented in the International Symposium on Industrial Toxicology held at Lucknow, India, on 4-7th November, 1975. 


\section{G. S. SHUKLA AND S. V. CHANDRA}

\section{Materials AND Methods}

Male albino rats weighing $130 \pm 10 \mathrm{~g}$ of I.T.R.C. colony were randomly allocated to four groups. The dietary and treatment schedule to those animals was as follows.

1. Group 1 (normal controls) comprising of ten rats were given basal synthetic diet as described by Pollack et al. ${ }^{8}$ ) throughout the experiment. After 15 days of commencing the experiment the rats were given daily intraperitoneal injections of $0.5 \mathrm{~m} l$ physiological saline for a period of another 15 days.

2. Group 2 (Manganese treated) consisting of another 10 rats were given basal synthetic diet throughout the experiments. $0.5 \mathrm{ml}$ physiological saline in the similar manner and for the same period as in group 1.

3. Group 3 (Iron deficient) having 10 rats were rendered iron deficient by maintaining them on iron free diet for 15 days $^{8}$ ) followed by the diet containing $\mathrm{FeSO}_{4} \cdot 7 \mathrm{H}_{2} \mathrm{O}$, $47 \mathrm{mg} / 100 \mathrm{~g}$ (half of daily required iron) for another 15 days. The animals were given daily intraperitoneal injections of $0.5 \mathrm{ml}$ physiological saline during the later half of the experimental period.

4. Group 4 (Iron deficient and manganese treated) consisting of 20 rats were rendered iron deficient by giving the same diet as in group 3. They were then given daily intraperitoneal injections of $\mathrm{MnCl}_{2} \cdot 4 \mathrm{H}_{2} \mathrm{O}(15 \mathrm{mg} / \mathrm{kg})$ for 15 days in the later half of the experimental period.

The diet to all the animals was given in procelain dishes and water was given adlibitum. The animals were maintained under standard laboratory conditions throughout the experiment. Weekly weight was recorded and haemoglobin estimations were done from the blood of tail vein of each rat at day 15 and at the termination of the experiment.

All the animals were sacrificed at day 30 by decapitation, brain was taken out immediately and was inspected for any gross pathological change. Brain was then divided into two halves by median saggital section, one half was fixed in buffered formalin for routine histopathological examination. The other half was used for enzymic assays and for the estimation of manganese contents.

Histopathological examination. After brief fixation in buffered formalin, brain tissue was dehydrated and embedded in paraffin. $5 \mu$ sections were stained with heamatoxylineosin, Luxol fast blue and carbol thionine ${ }^{9}$.

\section{Enzyme assays}

Homogenates were prepared from weighed portions of brain (cut into several small pieces) in an appropriate media in a chilled Potter-Elvehjem homogenizer for the activity of various enzymes.

Succinic dehydrogenase (SDH) [Succinate: (acceptor) Oxidoreductase, E.C. 1.3.99.1] 


\section{MANGANESE TOXICITY IN IRON DEFICIENT RATS}

activity was determined according to the procedure of Slater and Bonner ${ }^{10}$. Acetylcholine esterase (AChE [Acetylcholine hydrolase, E.C. 3.1.1.7] activity was assayed as described by Hestrin ${ }^{11}$. The activity of monoamine oxidase (MAO Monoamine : oxygen oxidoreductase (deaminating) E.C. 1.4.3.4] was determined in $0.1 \mathrm{M}$ sodium potassium phosphate buffer, $\mathrm{pH} 7.2$ at $37^{\circ}$ using benzylamine hydrochloride as substrate [Orthophosphoric monoester phosphohydrolase (acid optimum) E.C. 3.1.3.2) and alkaline phosphatase (Orthophosphoric monoester phosphohydrolase (alkaline optimum) E.C. 3.1.3.1] activities were determined according to the procedure of Wooton ${ }^{13)}$.

Protein contents in the brain tissue were estimated by the method of Lowry et al. ${ }^{14)}$ using bovine serum albumin as standard. Manganese contents were determined by the method described by Shukla et al.15) in Perkin-Elmer model 303 atomic absorption spectrophotometer.

Statistical significance between control and experimental values were calculated according to the test described by Fisher ${ }^{16)}$. $\mathrm{P}$ values less than 0.05 were considered to be significant.

\section{RESUlts}

The animals which were maintained on iron deficient diet (groups $3 \& 4$ ) became weak and lost weight as compared to animals of groups 1 and 2 . The body weight of iron deficient animals at the time of sacrifice were on an average $40 \%$ (120 g) below the average of groups 1 and $2(200 \mathrm{~g})$.

None of the animals died from the groups given normal synthetic diet. 2 animals died from iron deficient group and 6 animals died from group 4 (iron deficient and manganese treated). The cause of death could not be ascertained.

The animals of group 3 and 4 became progressively anaemic as was indicated by 18 and $30 \%$ decrease in their haemoglobin contents $(\mathrm{g} / 100 \mathrm{~m} l)$ at day 15 and 30 respectively as compared to the animals in groups 1 and 2 .

\section{Neuropathological observations}

Gross. The brain in rats of all the groups appeared normal. The meninges were thin and delicate and cerebral hemispheres symmetrical, revealing no abnormality. The ventricular system was bilaterally symmetrical. Coronal sections at various levels of the brain did not reveal any abnormality and blood vessels were also normal in all the groups.

Microscopic. Sections from cerebral cortex, corpus striatum, diencephalon, cerebellum and brain stem were normal in the rats of groups 1,2 and 3 (Fig. 1). Sections from cerebral cortex of iron deficient manganese treated rats (group 4) showed occasional neuronal degeneration and neuroglial proliferation (Fig. 2). Some of the astrocytes were awollen and nuclei in them were pushed to one side. Luxol fast blue staining did not reveal any abnormality in the white matter. Blood vessels appeared normal. 


\section{G. S. SHUKLA AND S. V. CHANDRA}

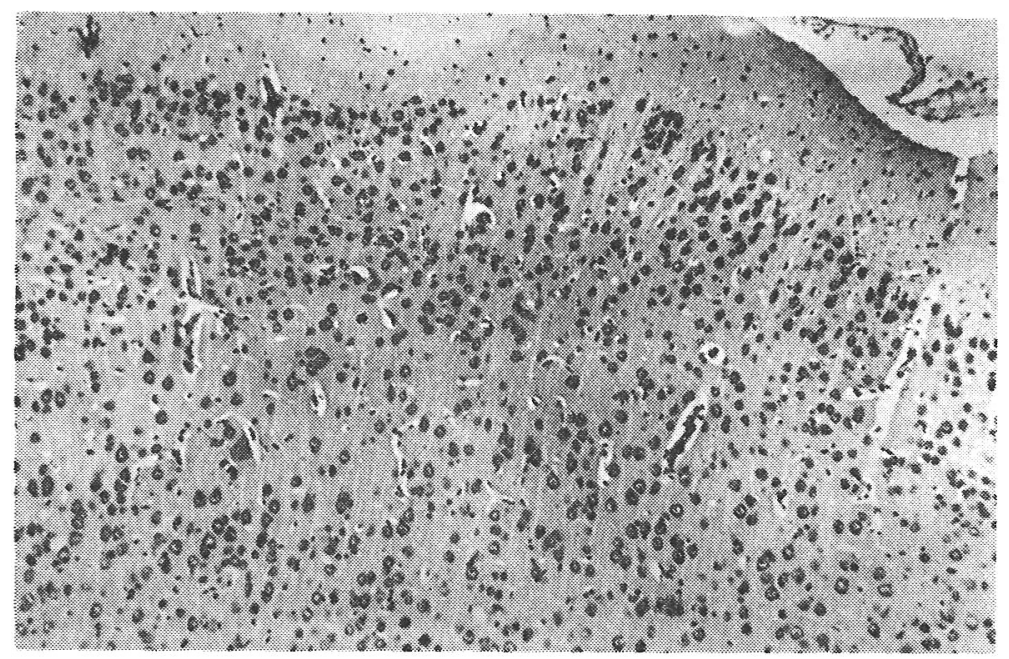

Fig. 1. Section of cerebral cortex of control rat showing normal structure. $\mathrm{H} \& \mathrm{E} \times 145$.

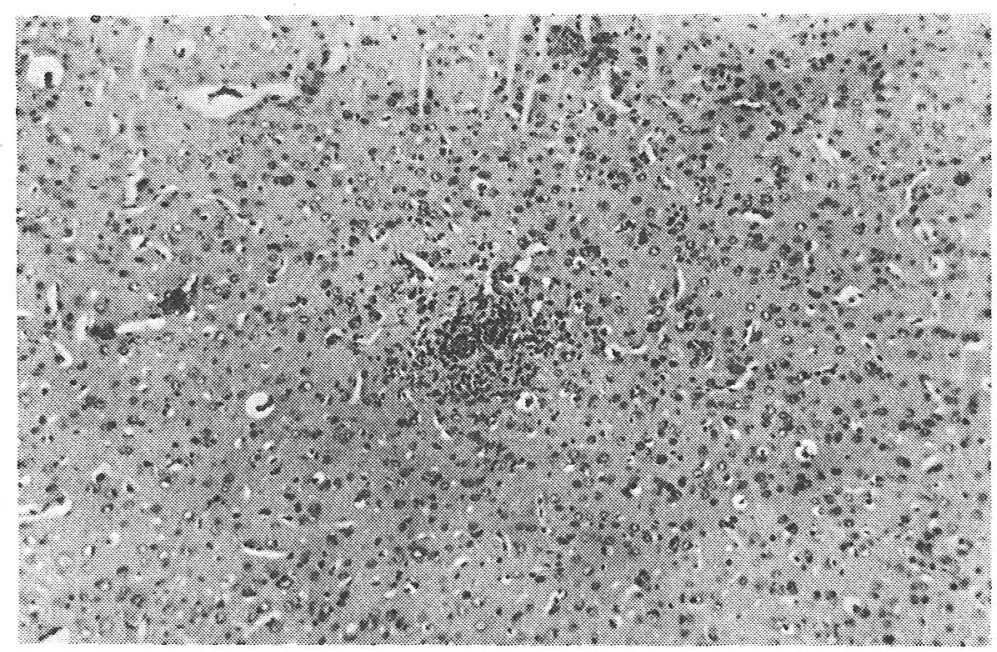

Fig. 2. Section of cerebral cortex of iron deficient manganese treated rat showing occasional neuronal degeneration and neuroglial proliferation. $\mathrm{H} \& \mathrm{E} \times 145$.

Biochemical observatsons. The activity of various enzymes together with protein and manganese contents are shown in Table 1.

Manganese treatment to normally fed rats produced significant decrease in the activity of SDH $(p<0.01)$ and a highly significant $(p<0.001)$ increase in the activity of MAO as compared to controls. Iron deficiency per se produced a slight decrease in the activity of MAO and alkalin phosphatase while other enzymes were note affected. Manganese administration to iron deficient animals produced marked alterations in the activity of all the anzymes assayed in the brain tissue. There was significant decrease in the 


\section{MANGANESE TOXICITY IN IRON DEFICIENT RATS}

Table 1. Activity of enzymes, protein and manganese contents in brain of rats of various groups.

\begin{tabular}{|c|c|c|c|c|}
\hline Enzymes & $\begin{array}{l}\text { Group } 1 \\
\text { (Control) }\end{array}$ & $\begin{array}{l}\text { Group } 2 \\
\text { (Manganese } \\
\text { treated) }\end{array}$ & $\begin{array}{c}\text { Group } 3 \\
\text { (Iron deficient) }\end{array}$ & $\begin{array}{l}\text { Group } 4 \\
\text { (Iron deficient } \\
\text { + manganese } \\
\text { treated) }\end{array}$ \\
\hline $\begin{array}{l}\text { Succinic dehydrogenase (nmole of } \\
\mathrm{K}_{3} \mathrm{Fe}(\mathrm{CN})_{6} \text { reduced } / \mathrm{min} / \mathrm{mg} \text { protein) }\end{array}$ & $10.91 \pm 0.33$ & $\begin{array}{l}9.31 \pm 0.27 \\
\mathrm{p}<0.01\end{array}$ & $\begin{array}{l}10.94 \pm 0.35 \\
\text { n.s. }\end{array}$ & $\begin{array}{l}7.22 \pm 0.34 \\
\mathrm{p}<0.001\end{array}$ \\
\hline $\begin{array}{l}\text { Monoamine oxidase (nmole of benzal- } \\
\text { dehyde formed } / \mathrm{min} / \mathrm{mg} \text { protein) }\end{array}$ & $3.13 \pm 0.10$ & $\begin{array}{l}4.28 \pm 0.11 \\
\mathrm{p}<0.001\end{array}$ & $\begin{array}{c}2.84 \pm 0.08 \\
\mathrm{p}<0.05\end{array}$ & $\begin{array}{l}5.29 \pm 0.19 \\
\mathrm{p}<0.001\end{array}$ \\
\hline $\begin{array}{l}\text { Acetylcholinesterase (nmole of acetyl- } \\
\text { choline hydrolyzed } / \mathrm{min} / \mathrm{mg} \text { protein) }\end{array}$ & $100.93 \pm 2.72$ & $\begin{array}{l}104.21 \pm 2.91 \\
\text { n.s. }\end{array}$ & $\begin{array}{c}96.06 \pm 2.98 \\
\text { n.s. }\end{array}$ & $\begin{array}{c}85.08 \pm 2.30 \\
\mathrm{p}<0.01\end{array}$ \\
\hline $\begin{array}{l}\text { Alkaline phosphatase (nmole of phenol } \\
\text { liberated } / \mathrm{min} / \mathrm{mg} \text { protein }\end{array}$ & $16.60 \pm 0.48$ & $\begin{array}{l}15.04 \pm 0.22 \\
\text { n.s. }\end{array}$ & $\begin{array}{c}14.01 \pm 0.27 \\
\mathrm{p}<0.001\end{array}$ & $\begin{array}{l}10.09 \pm 0.17 \\
\mathrm{p}<0.001\end{array}$ \\
\hline $\begin{array}{l}\text { Acid phosphatase (nmole of phenol } \\
\text { liberated } / \mathrm{min} / \mathrm{mg} \text { protein) }\end{array}$ & $9.07 \pm 0.24$ & $\begin{array}{l}9.04 \pm 0.28 \\
\text { n.s. }\end{array}$ & $\begin{array}{l}8.37 \pm 0.22 \\
\text { n.s. }\end{array}$ & $\begin{array}{c}6.89 \pm 0.17 \\
\mathrm{p}<0.001\end{array}$ \\
\hline Protein (mg/g) & $98.82 \pm 5.21$ & $\begin{array}{l}100.01 \pm 6.01 \\
\text { n.s. }\end{array}$ & $\begin{array}{c}97.89 \pm 3.36 \\
\text { n.s. }\end{array}$ & $\begin{array}{l}98.38 \pm 4.30 \\
\text { n.s. }\end{array}$ \\
\hline $\begin{array}{l}\text { Manganese ( } \mu \mathrm{g} / \mathrm{g} \text { wet weight of } \\
\text { tissue) }\end{array}$ & $0.73 \pm 0.059$ & $\begin{array}{l}1.22 \pm 0.056 \\
\mathrm{p}<0.001\end{array}$ & $\begin{array}{l}0.84 \pm 0.070 \\
\quad \text { n.s. }\end{array}$ & $\begin{array}{c}1.86 \pm 0.060 \\
p<0.001\end{array}$ \\
\hline
\end{tabular}

Values represent the mean of 6 determinations \pm S.E. Probability evaluated by student ' $t$ ' test. n.s. not significant.

activity of $\mathrm{SDH}, \mathrm{AChE}$, acid and alkaline phosphates while MAO activity was markedly increased.

The contents of protein in all the groups remained within normal limits. The content of manganese in the brain of control rats was $0.73 \pm 0.06 \mu \mathrm{g} / \mathrm{g}$ fresh weight of tissue. The content increased significantly $(1.22 \pm 0.05 \mu \mathrm{g} / \mathrm{g}$ fresh weight of tissue) in the brain tissue of manganese administered normally fed rats. Iron deficiency alone did not alter the content of manganese in the brain as compared tn controls. The maximum increase in the contents of manganese $(1.86 \pm 0.06 \mu \mathrm{g} / \mathrm{g}$ fresh weight of tissue) occured in the brain of manganese treated iron deficient rats.

\section{Discussion}

In the present study the rats were rendered iron deficient by maintaining them on iron deficient diet which does not deplete them of any nutrient except iron ${ }^{8}$. Daily intraperitoneal administration of $\mathrm{MnCl}_{2} \cdot 4 \mathrm{H}_{2} \mathrm{O}(15 \mathrm{mg} / \mathrm{kg})$ for 15 days to iron deficient rats produced morphological and enzymic alterations in the brain tissue to a much greater extent as compared to those seen after similar treatment to rats fed on basal diet. The content of manganese in the brain was also maximum in manganese treated iron deficient animals. It clearly indicates that manganese administration is more injurious to the brain tissue of iron deficient rats which appears to be due to increased content of the metal in the brain of these animals.

Interrelationship of manganese and iron have been noted in many ways, chemistry 


\section{G. S. SHUKLA AND S. V. CHANDRA}

of manganese and iron are similar, both tend to coordinate with six ligands and from octahedral complexes. Manganese is also incorporated in haemoglobin molecule ${ }^{17}$. Their relationship in biological system have been noted in their similar behaviour during absorption from intestines ${ }^{8}$. Many investigators have reported greater absorption and accumulation of manganese in the body tissues in iron deficiency ${ }^{2,3}$. The present finding of greater accumulation of manganese in the brain of iron deficient animals is in confirmation with these reports. It has also been observed that the extent of brain damage due to manganese is correlated with the amount of metal content in this tissue ${ }^{18}$.

Iron deficiency, particularly in the industrial workers of developing counties, may be one of the biggest metabolic factor in rendering an individual more susceptible to manganesetoxicity. It is, therefore, suggested that the workers in manganese industry should be checked frequently for iron deficiency as a prophylactic measure in manganese toxicity.

\section{Acknowledgements}

Authors are grateful to Shri R.S. Srivastava, Shri I. Ansari for their technical help and Shri M. Ahmad for photomicrography.

\section{REFERENCES}

1) Tolonen, M. (1972). Work-Environ. Health., 9, 53.

2) Mena, I., Horiuchi, K., Burke, K. and Cotzias, G. C. (1969). Neurology, 19, 1000.

3) Chandra, Satya V. and Tandon, S. K. (1973). Environ. Physiol. Biochem., 3, 230.

4) Chandra, S. V. and Shukla, G. S. (1976). Arch. Toxikol., In press.

5) Mella, H. (1924). Arch. Neurol. Psychiat., 11, 405.

6) Pentschew, A., Ebner, F. F., Kovatch, R. M. (1963). J. Neuropathol. Exp. Neurol. 22, 488.

7) Chandra, S. V. (1972). Arch. Toxikol., 29, 29.

8) Pollack, S., James, N., George, R. C., Kaufman, R. M. and Crosby, W. H. (1965). J. Clin. Invest., 44, 1470.

9) MacManus, J. F. A. and Mowry, R. W. (1965). Staining Methods: Histologic and Histochemical. : Hoeber Medical Division, Harper \& Row, New York.

10) Slater, E. C. and Bonner, W. D. (1952). Biochem. J., 52, 185.

11) Hestrin, S. (1949). J. Biol. Chem., 180, 249.

12) McEwen Jr. Charles M. (1971). Methods in Enzymology Vol. XVII B, p. 686-692. Academic Press, New York.

13) Wooton, I. D. P. (1964). Microanalysis in Medical Biochemistry. 4th ed. pp. 107, J \& A Churchill Ltd., London.

14) Lowry, O. H., Rosebrough, N. J., Farr, A. L. and Randall, R. J. (1951). J. Biol. Chem., 193, 265.

15) Shukla, G. S., Chandra, S. V. and Seth, P. K. 39,00-00, (1976). Acta Pharmacol. Toxikol. (in press).

16) Fisher, R.A. (1950). Statistical Methods for Research Workers. 11th Ed. Oliver \& Boyd, London.

17) Cotzias, G. C. (1958). Physiol. Rev., 38, 503.

18) Chandra, S. V. and Srivastava, S. P. (1970). Acta Pharmacol. 28, $177-$ 